\title{
A PEDTANTÁR.HU SZEREPE A SZAKMAI PEDAGÓGUSKÉPZÉS HÁLÓZATÁBAN
}

\section{HorvÁTH Cz. JÁNOS}

\author{
a Budapesti Müszaki és Gazdaságtudományi Egyetem \\ Gazdaság- és Társadalomtudományi Karának \\ egyetemi tanársegédje \\ horvath.cz.j@eik.bme.hu
}

\begin{abstract}
Jelen írásban ${ }^{1}$ bemutatásra kerülö fejlesztés célja a pedagógusképzö intézmények regionális szintü szolgáltató- és kutatóközpontjainak kialakitása, majd a kapcsolódó hálózati együttmüködés megteremtése volt. Az együttmüködés eszményét a közremüködö résztvevők éltetik, e nélkül nem kelhet életre semmiféle hálózat. Amennyiben a közös eröfeszitések eredményeként létrejön a hálózat, megerösitése és megtartása érdekében folyamatos szervezö, tájékoztató és ismeretfelhalmozó munkát kell végezni. E tevékenységek hatékony támogatására helyeztük üzembe a PEDTANTÁR.HU portált (http://pedtantar.hu/).
\end{abstract}

\section{Bevezetés}

Mind a hétköznapi, mind a szakmai közbeszédben egyre gyakrabban kiemelt figyelmet kap a hálózat fogalma. Mi a hálózat? Miért fontos? Hogyan használjuk a hálózatokat céljaink eléréséért? Megannyi kérdés, amelyek közül néhányra pontos, míg másokra inkább csak elnagyolt válasz adható. A hálózat a matematika felöl megközelítve csomópontok és élek halmaza. Ezen összetevők gráfokat alkotnak, amelyek különleges tulajdonságait szintén matematikai eszközökkel ragadhatjuk meg. Az elvont szabályszerüségek akkor válnak fontossá, amikor hasznuk a köznapokban is érvényesül. Barabási (2008) igen részletesen tárgyalja azokat a hálózatszerveződési szempontokat, amelyek által az emberek között kialakuló kapcsolatrendszer kellően erőssé válhat, $s$ egyben szemlélteti, hogyan érvényesülnek a matematikai szabályok a mindennapokban. Itt és most nem lehetséges a Barabási-féle gyenge kapcsolatokon alapuló hálózatstabilitási elméletet, illetve az általa megfogalmazott pályázati alapelveket és lehetséges megvalósulásukat tárgyalni, de bemutatjuk azokat a megvalósított eszközöket, amelyeket a pályázat szellemiségének megfelelően és az ismert hatékony hálózatszervező irányvonalak mentén alkottunk meg.

\footnotetext{
${ }^{1}$ Az írásban hivatkozott pályázat azonosítója: TÁMOP-4.1.2-08/2/B/KMR-2009-0002
} 


\section{A támogató informatikai hálózat}

A pályázat ${ }^{2}$ tervezési szakaszában felmértük, hogy a közép-magyarországi régióban az együttmüködő partnerek nagy száma miatt szükséges valamilyen támogató informatikai rendszer. Olyan megoldást kerestünk, amellyel képessé válunk a szolgáltató és kutató hálózat tevékenységét segíteni, amelynek keretében az átalakuló szakmai és közismereti pedagógusképzés rendszerében egyrészt elősegíthetjük a tanárjelölt kollégáknak gyakorlati helyet biztosító iskolák megtalálását, másrészt a hatékony információáramlás révén a kutató tevékenységet folytató oktatók és pedagógusok is elérhetnek vagy éppen közreadhatnak lényeges írásokat, elemzéseket, dokumentumokat. Nem utolsó szempontként merült föl az érdeklödő nagyközönség tájékoztatása is, hiszen például leendő pedagógus-hallgatóként diákok, illetve a diákok szülei is betekinthetnek a pedagógusképzés világába.

Mindezek alapján választásunk egy LifeRay alapú portál rendszerre (http://www. liferay.com/) esett, amely a fenti célkitüzéseket sokoldalúan képes elérni. A rendszer nyílt forráskódú, így a programkódja szabadon elérhető, így a továbbiakban felmerülő fejlesztések vagy javítások útjában nem állnak gátló tényezők. A pályázat szerint kötelező öt éves fenntarthatóság a szoftver oldalról biztosított. A portált kiszolgáló hardver beszerzésével (amely teljesítményével a számítógépes infrastruktúránk egyik kiemelkedő egysége) megteremtettük az alapokat.

A portál a PEDTANTÁR nevet kapta, elérhetösége: http://pedtantar.hu/ vagy http://pedtantár.hu/ (ékezettel írva is elérhető az oldal). A nyitólapról a rendszer számos modulja is elérhető. Ezek a modulok rendre: „Hálózati tagok”, „Gyakorlóhelyek”, „Képzési kínálat”, „Közösségek”, „E-learning”, „Képtár”, „Wiki”. A modulok informatikai megoldásként lefedik a pályázatban vállalt hálózati feladatokat.

A pályázat keretén belül kialakítandó hálózat tagjainak névjegyét hoztuk létre. Partnereink között találjuk az Eötvös Loránd Tudományegyetemet (mint stratégiai partnert), a Moholy-Nagy Müvészeti Egyetemet, Óbudai Egyetemet, Szent István Egyetemet és a Budapesti Corvinus Egyetemet. A névjegyen belül a pedagógusképzéssel foglalkozó intézet aktuális elérhetősége található.

A pályázat keretében szolgáltatásként valósítottuk meg a gyakorlati időszaknak helyet adó, az oktatási intézmények közötti keresést lehetővé tevő digitális felületet. A rendszerben érintettek a tanárjelölt hallgatók, a fogadó iskolák, azon belül a mentortanárok, a küldő felsőoktatási intézmény megfelelö egysége és a gyakorlatra felkészítő oktatók. E sokszereplős helyzetben kellett megoldást találni úgy, hogy minden érintett a megfelelő időben és helyen kapjon visszajelzést, valamint ha bizonyos földrajzi területeken szükös kínálat alakulna ki, akkor ezt a versenyhelyzetet kezelni lehessen.

\footnotetext{
${ }^{2}$ TÁMOP-4.1.2-08/2/B/KMR-2009-0002
} 
A gyakorló helyek modulban a fogadó iskolák saját adatlapot vezetnek magukról, így a PEDTANTÁR.HU rendszerében szereplő oktatási intézmények egy új bemutatkozási felülethez is jutnak. A jelenlegi demográfiai helyzetben minden lehetőséget meg kell ragadni azért, hogy a leendő tanulók, tanárok érdeklődését felkeltsék. Ebben segíti őket ez a modul.

A „Képzési kinálat” a hálózati tagok számára kínál az előzőhöz hasonló megmutatkozást. Itt a hallgatók, valamint a tágabb környezet egyaránt tájékozódhat, hogy milyen felsőoktatási tanárképzésekből válogathatnak, milyen feltételek mellett tanulhatnak az adott intézményben. Ez a szolgáltatás is az érdeklődők számára nyújt segítséget az illetékes kapcsolattartók elérhetőségéhez.

A „Közösségek” menüpont alatt érvényesülnek leginkább a bevezetésben említett hálózatszervezési szempontok. A PEDTANTÁR.HU müködtetése során törekszünk arra, hogy minél kevésbé legyen szükség a központi információáramlás-irányításra. Úgy véljük, hogy ha a hálózat tagjai kis közösségekben, a többiektől többé-kevésbé elvonultan szeretnének dolgozni, akkor erre legyen lehetőség. A PEDTANTÁR.HU portálon regisztrált felhasználók tetszés szerint hozhatnak létre akár több közösséget is, és szabályozhatják digitális müködésüknek a nagyközönség által megismerhető részeit. Egy közösség számos oldalt hozhat létre, ahol különféle jól ismert eszközökkel tarthatják egymással a kapcsolatot (fórumok), vagy oszthatnak meg lényeges tartalmakat (állományok, wiki). Például az adott régió egy szakmában érdekelt szakpedagógusai létrehozhatják saját közösségüket, ahol elektronikus tananyagok felhasználásáról cserélhetnek eszmét, majd egy idő után közreadhatják az érdeklődők számára munkájuk eredményét.

A közösség tájékoztatása érdekében hoztuk létre a „Tudástár”, az „E-learning”, a „Képtár” és a ,Wiki” modult. A PEDTANTÁR.HU alkalmas felület arra, hogy megfelelően lektorált szakmai anyagokat helyezzenek el a résztvevők. A szakmai pedagógusképzés digitális könyvtárát teremtettük meg, és bízunk abban, hogy hamarosan gazdag gyüjteményt találnak itt a felhasználók. E-learning tananyagok külön fejezetet kaptak, hiszen a technikai fejlődés kikerülhetetlenné tette ezt a témát. A Képtár remek lehetőség arra, hogy a hálózati partnerek, a gyakorló iskolák és a regisztrált felhasználók olyan médiatartalmakat helyezzenek el, amelyek a szakmai pedagógusképzésben érintettek minden szintjének tájékozottsági szintjét emelik. Végül a Wiki olyan internetes lexikon lehet, ahol nevesített szakemberek írnak jó minőségủ szócikkeket a szakma bizonyos témáiról, így segítve a hallgatók és a nagyközönség tájékozódását, illetve felkészülését.

\section{Összefoglalás és kitekintés}

Ahogy áttekintettük a PEDTANTÁR.HU szolgáltatásait, bizonyára felmerült az a kérdés, hogy miért nem egy jól ismert nemzetközi közösségi hálózaton (Facebook, Google+) valósítottuk meg terveinket. A válasz véleményem szerint többrétegü 
(Horváth, 2011). Egyrészt ezek a közösségi oldalak változó jogi, pénzügyi és szolgáltatási környezettel bírnak, ami a hosszú távú fenntarthatóság esetében bizonytalansági tényezőnek tekinthető. Másrészt ezek a portálok profit-orientáltságuknak megfelelő eszköztárral müködnek, és ez a mi esetünkben nem biztos, hogy egybe esik a szakmai pedagógusképzést legjobban támogatni képes informatikai megoldásokkal. Harmadrészt fölmerül az adatvédelem kérdése (esetünkben az adatok országon belül maradnak és nem képezik semmilyen reklámhadjárat alapanyagát).

Elképzelésünkben egy olyan ernyőszerü portál volt, amely a nagy hírportálok szerepét tölti be a pedagógusképzés hálózati rendszerében: igyekszik sok témát megragadni, sokszínüségével nem csak tájékoztat, hanem kedvet ébreszt a tájékozódásra (Benedek, 2011; Szabóné, 2010). A közösségszervezést és a médiahasználatot illetően a korszerü Web2.0-ás szemlélet és eszközök alkalmazására törekedtünk annak érdekében, hogy egy új és korszerü portállal katalizáljuk a hazai (szakmai) pedagógusképzés hálózati rendszerének mielöbbi kialakulását és megerösödését.

\section{Irodalom}

Barabási-Albert László (2008): Behálózva. A hálózatok új tudománya. Helikon, Budapest.

Benedek András (2011): Új hálózati konstrukciók és partnerség a tanárképzésben. Pedagógiai Mühely, 1. sz. 5-10.

Benedek András, Szabóné Berki Éva (2011): Szakmai tanárképzés-tradíciók és új késztetések. In: Horváth Cz. János (2011): Hálózatépités eszközei a szakmai pedagógusképzésben. Poszter előadás. XI. Országos Neveléstudományi Konferencia, ELTE, 2011. november 4-6.

Horváth Cz. János (2011): Hálózatépités eszközei a szakmai pedagógusképzésben. Poszter előadás. XI. Országos Neveléstudományi Konferencia, ELTE, 2011. november 4-6.

Szabóné Berki Éva (2010): A Budapesti Mű́szaki és Gazdaságtudományi Egyetem innovációja a szakmai pedagógusképzésben. Szakképzési Szemle, 2. sz. 182-190. 